DOI: 10.46340/eppd.2020.7.3.15

Liubomyr Lonevskyi

ORCID ID: https://orcid.org/0000-0002-2419-5901

Lviv State University of Internal Affairs, Ukraine

\title{
STAGES OF THE DEVELOPMENT \\ OF LEGAL REGULATION OVER THE USE \\ OF OPERATIVE-SEARCH ACTIVITY RESULTS IN UKRAINIAN LEGISLATION
}

\author{
Любомир Лоневський \\ Львівський державний університет внутрішніх справ, Україна \\ ЕТАПИ РОЗВИТКУ НОРМАТИВНО-ПРАВОВОЇ \\ РЕГЛАМЕНТАЦІї ВИКОРИСТАННЯ РЕЗУЛЬТАТІВ \\ ОПЕРАТИВНО-РОЗШУКОВОЇ ДІЯЛЬНОСТІ \\ В УКРАЇНСЬКОМУ ЗАКОНОДАВСТВІ
}

The article analyzes the development of norms that at different times were components of the legal institution of the use of operative-search activity results in the legislation that operated on the territory of modern Ukraine. Based on the study of such regulations in relation to historical events that took place, it was concluded that there are grounds for the selection of six stages of its development, which include the following periods - before 1864, after 1864 to 1917, after 1917 to 1960 year, after 1960 to 2012, after 2012 to the present. As well there are grounds for allegations that the driving force of change in this legal institution were the processes of sociopolitical transformations that took place in our country, which components were views on human rights and freedoms and the grounds, forms, methods of their restriction during the detection and investigation of crimes.

Keywords: normative-legal regulation, stages of development, use of results of operative-search activity, criminal proceedings, results of operative-search activity, legal institute.

Постановка проблеми. Історія сучасного правового інституту використання результатів оперативно-розшукової діяльності у кримінальному провадженні неодноразово привертала увагу науковців, які займалися його дослідженням. Аналіз наукової літератури 3 цього питання та співставлення напрацювань науковців з подіями, які відбулися за часів незалежності України, свідчить про те, що в них не в повній мірі враховані особливості розвитку цього правого інституту, зокрема, з 2000 року по сьогодення. Це, у свою чергу, створило ситуацію, коли в теорії оперативнорозшукової діяльності та кримінального процесу не достатньо систематизовані уявлення про історичний контекст змін, які відбувалися у вітчизняному законодавстві протягом сучасної історії нашої держави. Без знань про чинники, які обумовили такі зміни, неможливо здійснити якісну оцінку результативності таких перетворень і підстав для подальших ініціатив щодо вдосконалення нормативних приписів щодо використання результатів оперативно-розшукової діяльності у кримінальному провадженні.

Аналіз останніх досліджень і публікацій. Питанням розвитку правового інституту використання результатів оперативно-розшукової діяльності присвячували свою увагу К.В. Антонов, А.Я. Алексеєв, В.В. Вапнярчук, Ю.М. Грошевий, О.Ф. Долженков, В.І. Зажицький, С.А. Кіріченко, О.І. Козаченко, Д.Й. Никифорчук, М.А. Погорецький, Д.Б. Сергеєва, В.В. Шендрик, М.Є. Шумило та інші науковці, завдяки яким сформувався традиційний підхід до розвитку цього правового інституту, в рамках якого виділяються дорадянський період, радянська доба до прийняття КПК України 1960 року, радянська доба після прийняття КПК України 1960 року, період незалежності України після прийняття Закону України «Про оперативно-розшукову діяльність». Однак, вплив реформ кримінального судочинства 2000 та 2012 років на історію правового інституту 
використання результатів оперативно-розшукової діяльності та їх взаємозв'язок із попередніми етапами його розвитку достатньо не досліджувався.

Метою цієї статті є дослідження етапів розвитку нормативно-правової регламентації використання результатів оперативно-розшукової діяльності в українському законодавстві.

Виклад основаних положень. Перший етап розвитку нормативно-правової регламентації використання результатів оперативно-розшукової діяльності був до 1864 року. За період дії Зводів Законів Російської Імперії $(1832,1842,1857)$, до яких були включені положення Судєбніка великого князя Івана III (1497), Судєбніка Царя і Великого князя Івана IV (1550), Уставна книга розбійного наказу (1555), Соборного Уложенія Царя Олексія Михайловича (1649), Краткого зображення процесів та судових тяжеб (1715), Статуту благочінія (1782), органи та окремі службові особи поліції мали повноваження як на здійснення розшукових дій, спрямованих на виявлення злочинів шляхом отримання відомостей з людських чуток, повідомлень, доносів, повальних обшуків, затримання винних при вчиненні злочину, так і на здійснення попереднього слідства по них, а також розшуку злочинців, які переховуються від слідства, суду та відбування покарання ${ }^{1}$. Вбачалося, що наявність у поліції таких повноважень забезпечує швидке реагування з боку державної влади на вчинені правопорушення та притягнення винних до кримінальної відповідальності. Однак, низький рівень спеціальної освіти, а подекуди її повна відсутність у працівників судових органів, прокуратури, не говорячи вже про поліцію, призводили до постійних зловживань ними своїм службовим становищем та хабарництва ${ }^{2}$. Усвідомлення того, що кримінальний процес повинен будуватися не тільки на підставі положень норм кримінального права про злочин та покарання за для забезпечення їх відповідного застосування, а його основною задачею $є$ забезпечення встановлення істини про обставини події злочину та причетних до неї осіб, запорукою якої $є$ гласність, усність, змагальність, участь суспільного елементу, незалежність судової влади, самостійність іiі органів, раціональне розподілення їх функцій, вільна оцінка доказів, простота, швидкість процесу та розбудова його на принципах гуманізму - все це стало підгрунтям прийняття у 1857 році Олександром II рішення про розробку нового окремого Статуту кримінального судочинства ${ }^{3}$. Однак, не очікуючи цього з метою початку розбудови правосуддя, яке грунтувалося б на відносно ліберальних принципах та на основі досвіду окремих країн Західної Європи, у переважній більшості Франції, Олександр II 08.06.1860 року видав Указ «Про відділення слідчої частини від поліції». Одночасно набули чинності такі нормативно-правові акти - «Установа судових слідчих», «Наказ судовим слідчим», «Наказ поліції щодо здійснення початкових досліджень по злочинах та проступках». Відповідно до «Установи судових слідчих» дізнання залишалося у віданні поліції та полягало у пошуку та відкритті обставин, які мають значення для розкриття злочину, затримання злочинця. Матеріали дізнання скеровувалися до судових слідчих для здійснення ними попереднього слідства ${ }^{4}$.

Другий етап розпочався з 1864 року з прийняттям Статуту кримінального судочинства Російської Імперії, у якому відбулося остаточне корегування співвідношення між поліцейським дізнанням, до засобів якого входили гласні та негласні розшукові дії, опитування, спостереження, та досудовим розслідуванням. Так, у ст. 254 цих Статутів зазначалося - «при провадженні дізнання поліція всі необхідні ій відомості збирає шляхом розшуку, словесними розпитами та негласним спостереженням, не проводячи ні обшуків ні виїмок в будинках» ${ }^{5}$. За Статутом кримінального судочинства дізнання не рідко називалося у широкому сенсі розшуком, через домінування у ньому

\footnotetext{
1 Линовский, В. (1849) Опыт исторических розысканий о следственном уголовном судопроизводстве в России. Одесса: Тип. Л. Нитче, $147-150$.

${ }^{2}$ Блинов, И.А. (1914). Фактическое состояние правосудия до реформы 1864 года. Судебные уставы 20 ноября 1864 года за пятьдесят лет. Петроград, 27-40; Шевчук, В.Б. (2004). Реформирование судебной системы в России во второй половине XIX - начале XX в. (историко-правовое исследование): диссертация кандидата юридических наук. Санкт-Петербург, 47-59.

${ }^{3}$ Блинов, И.А. (1914). Сознание необходимости судебной реформы. Судебные уставы 20 ноября 1864 года за пятьдесят лет. Петроград, Том первый, 53-100.

${ }^{4}$ Сорокина, Ю.В. (2014). Основные этапы реформы следственного аппарата и предварительного расследования в России 1860-1864 годов. Судебная власть и уголовный процесс, 3, 273-274.

${ }_{5}^{5}$ Свод Законов Российской Империи: в 16 т. (1912). T. 16. Ч. 1: Судебные уставы. Санкт-Петербург: Русское Книжное Товарищество «Деятель», 410.
} 
заходів пошукового характеру. Так, І.Я. Фойницький вказував, що сутність дізнання складає негласне поліцейське розслідування, на яке вказується уст. 312 Статуту кримінального судочинства ${ }^{1}$. А. Квачевський одним із перших здійснив спробу розкрити співвідношення дізнання та досудового (попереднього) слідства, писав: «Дізнання пов'язане із кримінальним переслідуванням, надаючи йому відомості, які необхідні для правильного пред'явлення вимоги на здійснення попереднього слідства щодо того злочину, який визначається цими відомостями і щодо особи, яке підозрюється завдяки ним. Дізнання знаходиться узв'язку із попереднім розслідуванням, тому що засвідчує дійсність злочину, який розслідується, дає підстави для початку слідства, встановлює відоме бачення слідчого на способи подальшого розкриття істини, на образ його дій відносно до обставин справи і до осіб, які беруть у ній участь. Але дізнання й відрізняється від слідства. Дізнання виробляє тільки відомості та вказівки, які не мають судового характеру; вся його роль обмежується пошуками відомостей для діяльності слідчого, сприяння їй, полегшенням ії; воно не має справи із судовими формами та обрядами, не оцінює фактів, не дає ніяких визначень про них, висновків, і тому може бути здійснене особами, які не належать до судового відомства. Попереднє слідство спрямоване на встановлення доказів протизаконності дії та провини злочинця, які засвідчуються в суді; займається обговоренням, оцінкою обставин справи; його форми та акти мають судове значення; тому воно здійснюється тільки особою судового відомства, і якщо певна доля слідчого провадження надається іншому діячеві, то не інакше, як із виконанням умов та обрядів, які вказані законом для судового слідчого» ${ }^{2}$. А. Квачевський маючи тривалий стаж роботи прокурором та суддею, застерігаючи від повернення до попередньої моделі поліцейської діяльності, обгрунтовував, що розпити, негласне спостереження є дійсно ефективними засобами для здійснення дізнання та розшуку. Але поєднання в руках людей нездібних таких засобів відкриття істини як обшуки, допити у поєднанні із розпитами та негласними спостереженнями, призведе до свавільного зловживання ними, істина від них буде втікати, будуть виконуватися тільки формальності, а сутності справи вони не осягнуть, і це вже було до набуття чинності Статутами 1864 року․․

Третьому етапу дали старт події 1917 року. Формування нового для нашої держави соціальнополітичного устрою, розбудова якого грунтувалася на ідеології класової боротьби, яка виправдовувала порушення прав та свобод людини, вплинула на те, що з кримінальнопроцесуального законодавства зникли нормативні приписи щодо наявності повноважень у органів правопорядку з метою забезпечення виконання завдань кримінального судочинства здійснювати оперативно-розшукові заходи. Так, у главі 8 КПК УРСР 1922 року, яка присвячена нормативноправовій регламентації дізнання, у порівнянні зі Статутом кримінального судочинства Російської Імперії, розшукова діяльність не визначалася як компонент процесуальної діяльності кримінальної міліції. Повноваження на здійснення розшукових (оперативно-розшукових) заходів, спрямованих на виявлення, запобігання, попередження та розкриття злочинів передбачалися на рівні відомчих нормативно-правових актів із грифами обмеження доступу «таємно», «цілком таємно» ${ }^{4}$ Подібна ситуація мала місце й у КПК УРСР 1927 року та у відомчих нормативно-правових актах щодо здійснення оперативно-розшукових заходів уповноваженими на це у різні часові проміжки розвитку системи правоохоронних органів - ОДПУ, НКВС-НКБД, МДБ, КДБ, МОСП, МВС. Як зазначають М.А. Погорецький, В.В. Зубенко та Л.М. Родік у період з 1928 по 1953 роки, у так званий «сталінський» період, нормативно-правова регламентація негласної роботи та ведення оперативних

\footnotetext{
${ }^{1}$ Курс уголовного судопроизводства И.Я. Фоницкого (1899). Санкт-Петербург: Тип. т-ва «Общественная Польза», том 2, 400.

2 Квачевский, А. (1867). Об уголовном преследовании, дознании и предварительном исследовании преступлений по судебным уставам 1864 года: теоретическое и практическое руководство. Санкт-Петербург: Тип. Ф.С. Сущинскаго, Часть вторая, 4-5.

${ }^{3}$ Квачевский, А. (1867). Об уголовном преследовании, дознании и предварительном исследовании преступлений по судебным уставам 1864 года: теоретическое и практическое руководство. Санкт-Петербург:

Тип. Ф.С. Сущинскаго, Часть вторая, 206.

4 Декрет о рабоче-крестьянской милиции (Положение) 1920 (Всероссийский Центральный Исполнительный Комитет Советов и Совета Народных Комиссаров). Систематический сборник важнейших декретов (1917-1920). Москва, 212-234; Декрет об организации милищии» от 09 февраля 1919 года 1919 (Совет Народных Комиссаров Украины). Собрание Узаконений и Распоряжений рабоче-крестьянского правительства Украины за 1919 год. 3-е изд. Ст. 96; Михайленко, П.П., Кондратьев, Я.Ю. (1997). История милиции Украинь в документах и материалах. Т. 1: 1917-1925. Киев: Генеза, 108, 112,113, 115, 118.
} 
обліків формувалася в умовах посилення каральної політики комуністичної партії під головуванням Й.В. Сталіна при фактичному ігноруванні положень про прокурорський нагляд за негласною роботою, зокрема за оперативно-розшуковими заходами органів дізнання ${ }^{1}$. Більш за це - однією з характерних рис кримінального провадження у цей період була можливість використання як підстав для притягнення до кримінальної відповідальності повідомлень від конфідентів, анонімних повідомлень, матеріалів спостережень за особою без належної їх перевірки за відсутності передбаченої для цього процедури у кримінально-процесуальному законодавстві. Це призвело до масових зловживань з боку співробітників правоохоронних органів, розповсюдження застосування катувань для одержання зізнань на фоні обгрунтування в теорії кримінального процесу, що при вирішенні судом основного для нього завдання - встановлення істини має відбуватися в контексті суспільно-політичної оцінки поведінки обвинуваченого ${ }^{2}$. Г.І. Кочаров у вступі до однієї з фундаментальних робіт з теорії доказування у кримінальному провадженні, виданій у 1966 році, констатував, що у другій половині 50-х років фахівці у галузі кримінального процесу дійшли до остаточного висновку про неприпустимість спрощених процедур кримінального провадження, у яких ігнорується право особи на захист, домінування політичної доцільності над оцінкою доказів на предмет їх допустимості та достовірності ${ }^{3}$. У прагненні позбутися таких явищ та повернути довіру до системи правоохоронних органів 25.12.1958 був прийнятий Закон СРСР «Про затвердження основ кримінального судочинства Союзу РСР та союзних республік», на базі положень якого був розроблений та прийнятий у 1960 році КПК УРСР, з чого і починається четвертий етап розвитку нормативно-правової регламентації використання результатів оперативнорозшукової діяльності у кримінальному провадженні. У статті 103 КПК УРСР 1960 року визначалося, що «на органи дізнання покладається вжиття необхідних оперативно-розшукових заходів з метою виявлення ознак злочину і осіб, що його вчинили». Наведені нормативні приписи лягли в основу розвитку концепції оперативно-розшукової діяльності компонентами якої виступали уявлення, що:

- ця діяльність не є процесуальною, не дивлячись на те, що у кримінально-процесуальному кодексі визначалося, що оперативно-розшукові заходи можуть бути вжиті органом дізнання під час здійснення досудового розслідування;

- така діяльність передує досудовому розслідуванню або може його супроводжувати та має за мету попередження, припинення злочинів, а також розшук злочинців, що переховуються;

- суб'єктами такої діяльності є тільки уповноважені на їі здійснення оперативні підрозділи правоохоронних органів;

- основними засобами цієї діяльності є оперативно-розшукові заходи, засновані переважно на застосуванні негласних заходів і методів попередження, припинення злочинів, а також розшуку злочинців, що переховуються ${ }^{4}$.

В контексті нашого дослідження звернемо увагу, в першу чергу, на ту обставину, що виходячи з нормативних приписів ст. 103 КПК УРСР, в подальшому КПК України 1960 року, органи дізнання одержали повноваження з одного боку здійснювати процесуальні дії, приймати процесуальні рішення у кримінальних справах, а з іншого - здійснювати необхідні оперативно-розшукові заходи з метою виявлення ознак злочину i осіб, що його вчинили. При чому органи дізнання процесуальними повноваженнями щодо пред’явлення обвинувачення не наділялися. Це, як вказує

\footnotetext{
${ }^{1}$ Погорецький, М.А. (2007). Функціональне призначення оперативно-розиукової діяльності у кримінальному процесі: монографія. Харків: Арсіс, ЛТД, 69; Зубенко, В.В., Родік, Л.М. (2016). Історичні аспекти становлення оперативно-розшукової та слідчої діяльності. Судова та слідча практика в Україні, 1, 60.

2 Вышинский, А.Я. (1941). Теория судебньх доказательств в советском праве. Москва: Юрид. изд-во НКЮ СCCP, 18.

${ }^{3}$ Кочаров, Г.И., Миньковский, Г.М., Эйсман, А.А. и др. (1966). Теория доказательств в советском уголовном процессе: Часть общая. Москва: Изд-во «Юридическая литература», 7-13.

${ }^{4}$ Бондаренко, И. (1965). Основы оперативно-розыскной деятельности органов милиции УССР. Киев, 8; Кудрявцев, А.Я. (1966). Оперативно-розыскная деятельность органов охраны общественного порядка. Раздел 1: Основы оперативно-розыскной деятельности. Москва, 8; Гуткин, И.М. (1972). О соотношении понятий «оперативно-розыскные меры» и «розыскные действия» в советском уголовно-процессуальном законодательстве. 50 лет советской прокуратуры и проблемы совершенствования предварительного следствия. Ленинград, 60-63; Бакрадзе, А. (1968). Надзор за законностью оперативно-розыскных мер. Социалистическая законность, 2, 41-43.
} 
Л.В. Павлухін, обгрунтовувалося неприпустимістю поєднання в рамках повноважень слідчого одночасно оперативно-розшукової функції та функції розслідування кримінальних справ, через те, що можливе погіршення виконання кожної з цієї функцій. У випадках поєднання цих двох постійних функцій в руках одної посадової особи, наприклад, слідчого, в більшій мірі ніж різними посадовими особами, існує небезпека необ'єктивної, а тому неправильної оцінки зібраних доказів ${ }^{1}$. 3 наведеного видно, що з набуттям чинності КПК України 1960 року в цілому відбулося повернення до моделі співвідношення розшуку як складової поліцейського дізнання та досудового слідства, на здійснення якого був уповноважений судовий слідчий, яка мала місце у Статутах кримінального судочинства 1864 року. I як у 60-х роках 19 сторіччя так і за сто років по тому виключення з повноважень підрозділів, які мали право на здійснення оперативно-розшукової діяльності, притягнення до кримінальної відповідальності було викликано потребою устворенні умов, які суттєво зменшують імовірність зловживання повноваженнями з боку службових осіб органу досудового розслідування при вирішенні питання про притягнення особи в якості обвинуваченого у кримінальній справі. Однак, кримінально-процесуальний закон не містив нормативних приписів щодо використання в доказуванні результатів оперативно-розшукових заходів. У домінуванні процесуальної форми одержання доказів вбачалося забезпечення прав учасників кримінального провадження, особливо прав підозрюваного, обвинуваченого від свавільних дій органів правопорядку, які мали місце у попередньому періоді, але це суттєво обмежувало можливості залучення до сфери доказування у кримінальних справах даних, одержаних оперативними підрозділами органів правопорядку.

Як вірно зазначає В.І. Зажицький важливою подією на шляху подальшої правової регламентації оперативно-розшукової діяльності в рамках кримінально-процесуального законодавства стало прийняття 12.06.1990 Закону СРСР «Про внесення змін та доповнень до Основ кримінального судочинства Союзу РСР та союзних республік». Цим законом на органи дізнання покладалися обов'язки по здійсненню оперативно-розшукової діяльності з метою виявлення ознак злочинів та осіб, які їх вчинили, виявлення фактичних даних, які можуть бути використані в якості доказів по кримінальній справі після їх перевірки у відповідності до кримінально-процесуального законодавства. Він також передбачав обов'язок органів дізнання здійснювати оперативно-розшукові заходи з використанням відео- та звукозапису, фотозйомки, а також прослуховування телефонних та інших перемовин, які здійснюють з телефонів чи інших пристроїв для перемов². Але 16.07.1990 Верховною Радою Української РСР була проголошена Декларація про державний суверенітет України і ці нормативні приписи не були реалізовані. Однак, такі новели, розробка яких відбувалася за участі фахівців у галузі кримінального процесу та оперативно-розшукової діяльності на фоні загальних процесів демократизації суспільно-політичного життя, відкритості діяльності органів державної влади в рамках так званої «Перебудови» (комплексу політичних та економічних реформ, проголошених у 1985 році вищим політичним керівництвом СРСР), не залишилася поза уваги вітчизняного законодавця і 18.02.1992 Верховною Радою України був прийнятий Закон України «Про оперативно-розшукову діяльність». 3 цього моменту розпочався п’ятий етап розвитку нормативно-правової регламентації використання результатів оперативно-розшукової діяльності у кримінальному провадженні. На жаль ст. 10 Закону України «Про оперативно-розшукову діяльність», присвячена використанню матеріалів оперативно-розшукової діяльності, містила тільки визначення напрямів цього, а саме: 1) як приводи та підстави для порушення кримінальної справи або проведення невідкладних слідчих дій; 2) для отримання фактичних даних, які можуть бути доказами у кримінальній справі; 3) для попередження, припинення і розслідування злочинів, розвідувально-підривних посягань проти України, розшуку злочинців та осіб, які безвісти зникли; 4) для взаємного інформування підрозділів, уповноважених здійснювати оперативно-розшукову діяльність, та інших правоохоронних органів; 5) для інформування державних органів відповідно до їх компетенції. Але норм, які містили би порядок використання таких матеріалів а ні Закон України «Про оперативно-розшукову діяльність», а ні КПК України 1960 року, який був чинний на момент його прийняття не містили.

\footnotetext{
${ }^{1}$ Павлухин, Л.В. (1966). Дознание в советском уголовном процессе: автореферат диссертации кандидата юридических наук. Саратов: Саратовский юридический институт имени Д.И. Курского, 7-8.

2 Зажицкий, В.И. (2006). Результать оперативно-розыскной деятельности в уголовном судопроизводстве: теория и практика. Санкт-Петербург: «Юридический пресс центр», 20-21.
} 
Вдосконалення положень оперативно-розшукового та кримінально-процесуального законодавства щодо використання матеріалів оперативно-розшукової діяльності забезпечила «мала судова реформа», яка була обумовлена прагненням України імплементувати у вітчизняне законодавство європейські стандарти, зокрема, у сфері кримінального судочинства. 3 початку 18.01.2001 Законом України «Про внесення змін до Закону України «Про оперативно-розшукову діяльність» була запроваджена нова редакція ч. 2 ст. 8: «Негласне проникнення до житла чи до іншого володіння особи, зняття інформації з каналів зв’язку, контроль за листуванням, телефонними розмовами, телеграфною та іншою кореспонденцією, застосування інших технічних засобів одержання інформації проводяться за рішенням суду, прийнятим за поданням керівника відповідного оперативного підрозділу або його заступника. Про отримання такого дозволу суду або про відмову в ньому зазначені особи повідомляють прокурору протягом доби. Застосування цих заходів проводиться виключно з метою запобігти злочинові чи з'ясувати істину під час розслідування кримінальної справи, якщо іншим способом одержати інформацію неможливо. За результатами здійснення зазначених оперативно-розшукових заходів складається протокол з відповідними додатками, який підлягає використанню як джерело доказів у кримінальному судочинстві». А 21.06.2001 Верховною Радою України був прийнятий Закон «Про внесення змін до Кримінально-процесуального кодексу України», яким була запроваджена нова редакція ч. 2 ст. 65 КПК України 1960 року, у якій як джерела доказів були визначені протоколи 3 відповідними додатками, складені уповноваженими органами за результатами оперативно-розшукових заходів. Однак, процедура оформлення протоколів оперативно-розшукових заходів, механізм їх передавання органам досудового розслідування так і залишилася поза унормування.

3 прийняттям КПК України 2012 року розпочався шостий етап історичного розвитку норм, які регламентують використання результатів оперативно-розшукової діяльності. Розробники реформи кримінального судочинства, керуючись Рекомендаціями Комітету міністрів Ради Свропи державамчленам «Про «особливі методи розслідування» тяжких злочинів, у тому числі терористичних актів» N Rec (2005) 10 від 20.04.2005 ㄹ, з одного боку, кардинально змінили співвідношення оперативнорозшукової та кримінальної процесуальної діяльності, запровадивши до структури останньої негласні слідчі (розшукові) дії, а з іншого - реалізували загальноєвропейські стандарти у сфері використання результатів застосування особливих методів розслідування, до числа яких відносяться оперативно-розшукові заходи, яких не було на момент «малої судової реформи». Згідно 3 ними щодо оперативно-розшукових заходів у законодавстві має бути визначено: 1) обставини та умови, за яких компетентні органи правомочні їх застосувати; 2) можливість їх використання компетентними органами у тій мірі, в якій це необхідно в демократичному суспільстві для ефективного кримінального розслідування та переслідування; 3) належний судовий контроль та контроль іншими незалежними органами за їх застосуванням шляхом попередньої видачі дозволу на їх використання, контролю під час розслідування або подальшого перегляду; 4) механізм, що дозволяє представляти докази, отримані в результаті використання результатів оперативнорозшукових заходів, в суді (процесуальні норми, що регулюють надання та допустимість таких доказів, повинні гарантувати право обвинуваченого на справедливий судовий розгляд) $)^{2}$. Наведені параметри, хоча й носять рекомендаційний характер, але вони витікають із узагальнення багаторічної практики Свропейського суду з прав людини і їх реалізація має забезпечувати умови для системного захисту прав людини, передбачених у ст. 6, 8 Конвенції про захист прав людини і основоположних свобод, яка ратифікована Україною. Тому саме через призму практики Європейського суду з прав людини, досвіду нормативно-правової регламентації використання особливих методів розслідування у інших європейських державах мають аналізуватися положення ст. 8, 10 Закону України «Про оперативно-розшукову діяльність», абзаці другому ст. 99 та у главі 21 КПК України 2012 року та практика їх застосування щодо використання результатів оперативнорозшукової діяльності у кримінальному провадженні.

\footnotetext{
${ }^{1}$ Recommendations «On "special investigative techniques" serious crimes, including acts of terrorism» N Rec (2005) 10 of 20 April 2005 (Adopted by the Committee of Ministers on 20 April 2005 at the 924th meeting of the Minister's Deputies). $<$ http://www.legislationline.org/download/action/download/id/904/file/0e223d27a32f50234f2a029df7ee.pdf>.

${ }^{2}$ Recommendations «On "special investigative techniques" serious crimes, including acts of terrorism» N Rec (2005) 10 of 20 April 2005 (Adopted by the Committee of Ministers on 20 April 2005 at the 924th meeting of the Minister's Deputies). $<$ http://www.legislationline.org/download/action/download/id/904/file/0e223d27a32f50234f2a029df7ee.pdf>.
} 
Висновки. Дослідження генезису правового інституту використання результатів оперативнорозшукової діяльності дає підстави для:

- виділення шести етапів його розвитку, які включають такі періоди - до 1864 року, після 1864 року до 1917 року, після 1917 року до 1960 року, після 1960 року до 2012 року, після 2012 року до сьогодення;

- тверджень, що рушійною силою змін у цьому правовому інституті виступали процеси соціально-політичних трансформацій, які відбувалися на території нашої держави, компонентами яких були погляди на права і свободи людини та підстави, форми, способи їх обмеження під час розкриття та розслідування злочинів.

\section{References:}

1. Bakradze, A. (1968). Nadzor za zakonnost'ju operativno-rozysknyh mer [Supervision of the legality of operational investigative measures]. Socialisticheskaja zakonnost' [Socialist rule of law], no. 2, 41-43. [in Russian].

2. Blinov, I.A. (1914). Fakticheskoe sostojanie pravosudija do reformy 1864 goda [The actual state of justice before the 1864 reform]. Sudebnye ustavy 20 nojabrja 1864 goda za pjat'desjat let [Judicial Statutes of November 20, 1864 for fifty years]. Petrograd, 27-40. [in Russian].

3. Blinov, I.A. (1914). Soznanie neobhodimosti sudebnoj reformy [Awareness of the need for judicial reform]. Sudebnye ustavy 20 nojabrja 1864 goda za pjat'desjat let [Judicial Statutes of November 20, 1864 for fifty years]. Petrograd, Vol. 1, 53-100. [in Russian].

4. Bondarenko, I. (1965). Osnovy operativno-rozysknoj dejatel'nosti organov milicii USSR [The basics of operational-search activities of the police of the Ukrainian SSR]. Kyiv. [in Russian].

5. Vyshinskij, A.Ja. (1941). Teorija sudebnyh dokazatel'stv v sovetskom prave [Theory of judicial evidence in Soviet law]. Moscow: Jurid. izd-vo NKJu SSSR. [in Russian].

6. Gutkin, I.M. (1972). O sootnoshenii ponjatij «operativno-rozysknye mery» $i$ «rozysknye dejstvija» $v$ sovetskom ugolovno-processual'nom zakonodatel'stve. 50 let sovetskoj prokuratury i problemy sovershenstvovanija predvaritel'nogo sledstvija [On the correlation of the concepts of "operational-search measures" and "search actions" in the Soviet criminal procedure legislation. 50 years of the Soviet prosecutor's office and the problems of improving the preliminary investigation]. Leningrad. [in Russian].

7. Dekret o raboche-krest'janskoj milicii (Polozhenie) 1920 [Decree on Workers and Peasants' Militia (Regulation)] (Vserossijskij Central'nyj Ispolnitel'nyj Komitet Sovetov i Soveta Narodnyh Komissarov) [(All-Russian Central Executive Committee of Councils and Council of People's Commissars)]. Sistematicheskij sbornik vazhnejshih dekretov (1917-1920) [A systematic collection of the most important decrees (1917-1920)]. Moscow, 212-234. [in Russian].

8. Dekret ob organizacii milicii» ot 09 fevralja 1919 goda 1919 [Decree on the organization of police "of February 9 , 1919] (Sovet Narodnyh Komissarov Ukrainy) [(Council of People's Commissars of Ukraine)]. Sobranie Uzakonenij i Rasporjazhenij raboche-krest'janskogo pravitel'stva Ukrainy za 1919 god [Collection of Legalizations and Orders of the Workers 'and Peasants' Government of Ukraine for 1919]. 3-e ed. Art. 96. [in Russian].

9. Zazhickij, V.I. (2006). Rezul'taty operativno-rozysknoj dejatel'nosti v ugolovnom sudoproizvodstve: teorija $i$ praktika [The results of operational investigative activities in criminal proceedings: theory and practice]. Saint Petersburg: «Juridicheskij press centr». [in Russian].

10. Zubenko, V.V., Rodik, L.M. (2016). Istorychni aspekty stanovlennia operatyvno-rozshukovoi ta slidchoi diialnosti [Historical aspects of the formation of operational and investigative activities]. Sudova ta slidcha praktyka $v$ Ukraini [Judicial and investigative practice in Ukraine], no. 1, 60. [in Ukrainian].

11. Kvachevskij, A. (1867). Ob ugolovnom presledovanii, doznanii i predvaritel'nom issledovanii prestuplenij po sudebnym ustavam 1864 goda: teoreticheskoe i prakticheskoe rukovodstvo [On the criminal prosecution, inquiry and preliminary investigation of crimes under the judicial charters of 1864: theoretical and practical guidance]. Saint Petersburg: Tip. F.S. Sushhinskago, Part 2. [in Russian].

12. Kocharov, G.I., Min'kovskij, G.M., Jejsman, A.A. et al. (1966). Teorija dokazatel'stv v sovetskom ugolovnom processe: Chast' obshhaja [Evidence Theory in Soviet Criminal Procedure: Part General]. Moscow: Izd-vo «Juridicheskaja literatura». [in Russian].

13. Kudrjavcev, A.Ja. (1966). Operativno-rozysknaja dejatel'nost' organov ohrany obshhestvennogo porjadka. Razdel 1: Osnovy operativno-rozysknoj dejatel'nosti [Operational-search activity of public order protection bodies. Section 1: Fundamentals of operational investigative activities]. Moscow. [in Russian].

14. Kurs ugolovnogo sudoproizvodstva I.Ja. Fonickogo [The course of criminal proceedings I.Ya. Foynitsky] (1899). Saint Petersburg: Tip. t-va «Obshhestvennaja Pol'za», vol. 2. [in Russian].

15. Linovskij, V. (1849) Opyt istoricheskih rozyskanij o sledstvennom ugolovnom sudoproizvodstve $v$ Rossii [The experience of historical investigations into investigative criminal proceedings in Russia]. Odesa: Tip. L. Nitche. [in Russian].

16. Mihajlenko, P.P., Kondrat'ev, Ja.Ju. (1997). Istorija milicii Ukrainy v dokumentah i materialah [History of the Ukrainian police in documents and materials]. Vol. 1: 1917-1925. Kyiv: Geneza. [in Russian]. 
17. Pavluhin, L.V. (1966). Doznanie v sovetskom ugolovnom processe: avtoreferat dissertacii kandidata juridicheskih nauk [Inquiry in the Soviet criminal trial: Candidate's thesis of legal sciences]. Saratov: Saratovskij juridicheskij institut imeni D.I. Kurskogo. [in Russian].

18. Pohoretskyi, M.A. (2007). Funktsionalne pryznachennia operatyvno-rozshukovoi diialnosti u kryminalnomu protsesi: monohrafiia [Functional purpose of operative-search activity in criminal process: monograph]. Kharkiv: Arsis, LTD. [in Ukrainian].

19. Svod Zakonov Rossijskoj Imperii: v 16 tomah [The Code of Laws of the Russian Empire: in 16 volumes] (1912). Vol. 16. P. 1: Judicial Statutes. Saint Petersburg: Russkoe Knizhnoe Tovarishhestvo «Dejatel'». [in Russian].

20. Sorokina, Ju.V. (2014). Osnovnye jetapy reformy sledstvennogo apparata i predvaritel'nogo rassledovanija v Rossii 1860-1864 godov [The main stages of the reform of the investigative apparatus and preliminary investigation in Russia 1860-1864]. Sudebnaja vlast' i ugolovnyj process [Judicial branch and criminal process], no. 3, 273-274. [in Russian].

21. Shevchuk, V.B. (2004). Reformirovanie sudebnoj sistemy v Rossii vo vtoroj polovine XIX - nachale XX v. (istoriko-pravovoe issledovanie): dissertacija kandidata juridicheskih nauk [Reform of the judicial system in Russia in the second half of the 19th - beginning of the 20th centuries (historical and legal research): Candidate's thesis of legal sciences]. Saint Petersburg. [in Russian].

22. Recommendations «On "special investigative techniques" serious crimes, including acts of terrorism» N Rec (2005) 10 of 20 April 2005 (Adopted by the Committee of Ministers on 20 April 2005 at the 924th meeting of the Minister's Deputies). <http://www.legislationline.org/download/action/download/id/904/file/0e223d27a32f50234f2a029df7ee.pdf>. [in English]. 